\title{
Comparative Studies on Dynamics Soil Properties and Forms of Sulphur in Oilseed Growing Soils of Ambajogai Tahsil of Beed District
}

\author{
A. L. Dhamak* ${ }^{1}$, N. A. Meshram ${ }^{1}$ and S. L. Waikar \\ Department of Soil Science and Agricultural Chemistry, VasantraoNaikMarathwadaKrishiVidyapeeth, \\ Parbhani -431402, Maharashtra, India
}

\begin{abstract}
The present investigation was carried out to study the forms of sulphur and their relation to soil properties in oil seed growing soils of Ambajogai tahsil of Beed District.For this purpose 125 reprehensive soil samples were collected from different villages of Ambajogai tehsil and these soil samples were analyzed for physico-chemical properties and status of available $\mathrm{N}, \mathrm{P}, \mathrm{K}$, exchangeable Ca, Mg and forms of sulphur (Total sulphur, Available sulphur, Organic sulphur, Water soluble sulphur and Non-sulphate sulphur).The soils under the study areas were neutral to alkaline in reaction, safe in limit of electrical conductivity and moderately calcareous in nature.These soils were low to high content of organic carbon,low in available $N$ and $P$ and high in available $\mathrm{K}$. The exchangeable Ca was in sufficient quantity, while exchangeable $\mathrm{Mg}$ varied from low to high.The forms of sulphur present in these soils are in the order of total $S$, non-sulphate $S$, organic $S$, water soluble sulphate $S$ and available $S$. These soils are low to medium in available sulphur.The $\mathrm{pH}$ and $\mathrm{CaCO}_{3}$ were significantly negative correlated with all the forms of sulphur, whereas organic carbon showed significantly positive correlated with the different forms of sulphur. However, EC of soil did not reach to the level of significance.
\end{abstract}

Key Words: Soil properties, Ca, Mg, Organic Sulphur, Total Sulphur, Water soluble Sulphur.

\section{Introduction}

Sulphur is now being recognized as the fourth major nutrient in addition to nitrogen, phosphorus and potassium. The deficiencies of sulphur in soils and plants are being reported by several parts of the country and also from our state.The extent of S deficiency was 54 per cent in Maharashtra soils (Malewar and Syed Ismail, 1997). Sulphur occurs in sulphate ions in solution, adsorbed sulphate on exchange complexes, organically bound ester sulphates and organic sulphur complexes. The native sources of soil sulphur and metal sulphides occurring in igneous and sedimentary rocks. On oxidation, sulphides give rise to sulphates. Since, sulphur exists in soil in organic and inorganic combination; the inter-relationship of these pools with one another would help in predicting the response of crops to its application. The chemistry of sulphur was intensively studied in case of alluvial, red and laterite soils because of the fact that these soils are very poor in supply of available sulphur pool (Aulakh and Dev, 1976). Sulphur can be broadly grouped into five forms viz. total S, available sulphur, organic S, non sulphate S and water soluble S. Among these forms organic Sulphur is most important. Sulphur deficiency has become widespread in India especially in Vertisols and associated black soils. The nature and amount of various forms of $\mathrm{S}$ depend on variation in soil texture, $\mathrm{pH}$, calcium carbonate, organic matter and other soil characteristics. Distribution of different sulphur forms in soil decides the sulphur supplying power of soil by influencing its release and dynamics in soil. The soils of Beed district as a part of south central Maharashtra are developed on basaltic and metamorphic rocks of varying geological age and also on alluvium derived from such rocks. These soils are scientifically known as "Mixed MontmorilloniticHyperthermicTypicChromostert". Therefore, a comprehensive study on forms of sulphur in oilseed growing soils was undertaken to know the fertility status of soils of Ambagogai Tahsil of Beed district under Maharashtra state.

\section{Materials And Methods}

The study area of Ambajogai Tahsil of Beed district is located between $18^{0} 28^{\prime}$ to $19^{0} 28^{\prime}$ North altitude and $74^{0} 54^{\prime}$ to $76^{\circ} 57^{\prime}$ East latitude. The geographical area of the district is $10615.3 \mathrm{sq}$. km and it is 3.44 per cent of Maharashtra state. The annual rainfall of this district is in between $458 \mathrm{~mm}$ and $814 \mathrm{~mm}$. The maximum and minimum temperature of this district is $40.40^{\circ} \mathrm{C}$ and $17.68^{\circ} \mathrm{C}$, respectively. The elevation is 530 $\mathrm{m}$ from mean sea level. Beed is located on the Deccan Plateau, on the banks of `Bendsura` a sub-tributary of Godavari River. The soils are developed on basaltic and metamorphic rocks of varying age and also on alluvium derived from such rocks. The study area comes under zone of assured rainfall zone where tropical climatic conditions often exists(Hot Dry Subhumid Agroecological Region).In order to studies on forms of sulphur in oil 
seed growing soils of Ambajogai Tahsil of Beed District, one hundred and twenty five, representative surface $(0-0.20 \mathrm{~m})$ soil samples were collected, passed through $2 \mathrm{~mm}$ sieve and stored in properly labeled plastic bags. The soil $\mathrm{pH}$, EC, Organic Carbon, available $\mathrm{K}$, Exchangeable $\mathrm{Ca}$ and $\mathrm{Mg}$ were estimated by the standard procedures as described by Jackson (1973). The available $\mathrm{N}$ was analyzed by using alkaline potassium permanganate (Subbaiah and Asija, 1956). Available sulphur was determined by using $0.15 \% \mathrm{CaCl}_{2}$ solution(Williams and Steinberg, 1969) and sulphur bearing forms were determined (Chesnin and Yein, 1973; Evans and Rost, 1945).The whole data was subjected to statistical analysis by the method described by Panse and Sukhatme (1985).

\section{Chemical properties}

\section{Result And Disscussion}

Perusal data on the $\mathrm{pH}$ of Vertisols, Inceptisols and Entisols (Table1) varied from 6.02 - 8.89, 6.43 8.92 and 7.09- 8.43 with a mean value 7.71, 7.60 and 7.80, respectively. Thus, $\mathrm{pH}$ of all of the soils was recorded in more or less similar range. These values of $\mathrm{pH}$ indicate that all the soils under study were neutral to alkaline in reaction. The alkaline reaction of soil is probably due to the presence of sufficient free lime content and basaltic alluvium parent material rich in alluminosilicates and alkaline earth from which these are derived Jibhakate et al.(2009).The EC of the soils varied from $0.10-0.65,0.12-0.49,0.08-0.37 \mathrm{dSm}^{-1}$ in Vertisols, Inceptisols and Entisols, respectively. When EC exceeds $4 \mathrm{dSm}^{-1}$, the salt present become harmful to the growth of the crop. However, $<1.00 \mathrm{dSm}^{-1} \mathrm{EC}$ values considered as normal range. According to Jagtap (2007) noticed that the normal range of EC of soil of Chakur and Shirur- anantpal tahsil were observed from $0.13-0.79$ and $0.12-0.75 \mathrm{dSm}^{-1}$. The organic carbon content in the Vertisols, Inceptisols and Entisols ranged from 1.30 to $18.90,1.40$ to 15.00 and 1.40 to $11.40 \mathrm{~g} \mathrm{~kg}^{-1}$ with mean value $5.02,4.41$ and $3.94 \mathrm{~g} \mathrm{~kg}^{-1}$, respectively. Thus these soils are low to very high in organic carbon content. From the values of organic carbon, it was clearly depicted that the majority of soil samples are low to medium in range of organic carbon content. The content of organic carbon in soils depends on the range of precipitation within experimental area, considerable variation in precipitation is observed. Hot and dry climate is directly related with the temperature variation in the region/ecological unit. Low to medium content oforganic carbon is also attributed to the variation in decomposition rate (Yadav and Meena, 2009).The $\mathrm{CaCO}_{3}$ content in Vertisols, Inceptisols and Entisols ranged from 35.00 to $153.00,35.00$ to 147 and 37.00 to $114 \mathrm{~g} \mathrm{~kg}^{-1}$ with an average value $94.79,93.62$ and $81.00 \mathrm{~g} \mathrm{~kg}^{-1}$, respectively. This showed that most of the soil samples are calcareous in nature. Relative more accumulation of $\mathrm{CaCO}_{3}$ in Vertisols and associated black soils may be partly associated with their recent origin with rich in alkali earth and partly due to calcification process prevalent in this region (Mahesh kumar, 2011). A scan to the data onthe available N, P and K (Table1), suggested that majority of the soil sample are low in available nitrogen content. The lower content of available nitrogen in this area is associated with hot and dry climate climax. Low content of organic matter and low total nitrogen reserve and in term C: $\mathrm{N}$ ratio of immobilized forms of nitrogen was reported by Malewar(1995). The available phosphorus in Vertisols, Inceptisols and Entisols ranged from 1.14 to $20.62,1.03$ to 20.47 and 1.65 to $10.57 \mathrm{~kg} \mathrm{ha}^{1}$ with an average of $6.77,6.74$ and $5.82 \mathrm{~kg} \mathrm{ha}^{-1}$, respectively. Thus, these soils are very low to moderately high in available phosphorus content. The swell shrink soils of Maharashtra were very low to high in available P content as reported by Patil and Sonar (1994). However, available potassium in all soil groups was medium to very high. The available potassium content in Vertisols, Inceptisols and Entisols ranged from 118.70 to $844.60,120.80$ to 716.30 and 130.90 to $835.60 \mathrm{~kg} \mathrm{ha}^{-1}$ with mean value of 432.37, 427.26 and $414.29 \mathrm{~kg} \mathrm{ha}^{-1}$, respectively. Thus most of the soil samples contained high amount of available potassium. The high content of $\mathrm{K}_{2} \mathrm{O}$ is due to presence of $\mathrm{K}$ rich minerals in Vertisols and associated soils of Marathwada region(Vineethaand Malewar, 2007). The dominance of exchangeable $\mathrm{Ca}$ and $\mathrm{Mg}$ was observed in most of the soils. Higher exchangeable $\mathrm{Ca}$ and $\mathrm{Mg}$ are attributed to homogeneous parent material. High base saturation was due to presence of bases contributing minerals such as Zeolite in these black soils (Pal et al., 2006). The presence of Zeolites even in the present day climate indicates that loss of bases during leaching of soils has been continuously replenished by the steady supply of bases from these Zeolites and one responsible for more base saturation (Bhattacharyya et al., 1999).

\section{Sulphur forms}

The dataon total sulphur in Vertisols, Inceptisols and Entisols and their range from 19.50$3652.00,347.50-4300.00$ and 192.50 to $1625.00 \mathrm{mg} \mathrm{kg}^{-1}$ with an average of $1678.16,1172.78$ and $543.60 \mathrm{mg} \mathrm{kg}$ ${ }^{1}$, respectively (Table 1). Wide variation in the total $\mathrm{S}$ content in these soil orders may be due to greater heterogeneity in content of organic matter and parent material. Comparatively lower amounts of total $\mathrm{S}$ in the order Entisols might be due to lower content of clay and organic carbon. Dharakhnath et al. (1995) reported that the total S content in the Vertisols of the Maharashtra varied from 1125 to $2525 \mathrm{mg} \mathrm{kg}^{-1}$ with an average of $1788 \mathrm{mg} \mathrm{kg}^{-1}$. Also, the available sulphur in Vertisols,Inceptisols and Entisols ranged from 3.30-30.33,3.3228.92 and 2.42 to $28.85 \mathrm{mg} \mathrm{kg}^{-1}$ with an average $15.05,15.69$ and $15.95 \mathrm{mg} \mathrm{kg}^{-1}$ respectively. These soils are 
low to medium in available sulphur. Variations in available $\mathrm{S}$ in different soil order could be explained on the basis of variations in organic carbon, clay, $\mathrm{pH}$ and other physico-chemical characteristics of these soils. Mali and Syed Ismail (2002) recorded the available sulphur content in oilseed growing area of Gangakhed tahsil from 3.73 to $16.80,2.60$ to 17.60 and 1.37 to $16.06 \mathrm{mg} \mathrm{kg}^{-1}$ with the mean of $11.44,10.02$ and $7.10 \mathrm{mg} \mathrm{kg}^{-1}$ in Vertisols. The organic sulphur in Vertisols, Inceptisols and Entisols ranged from 3.00-84.30,11.36-176.00 and 10.96 to $120.30 \mathrm{mg} \mathrm{kg}^{-1}$ with an average $31.78,44.05$ and $57.85 \mathrm{mg} \mathrm{kg}^{-1}$,respectively.Variation in organic $\mathrm{S}$ was due to accumulation of organic matter and clay.These findings are in conformity with Borkotoki and Das (2008). While, the water soluble sulphate sulphur in Vertisols, Inceptisols and Entisols ranged from 4.80-58.26, $6.30-68.30$ and 5.20 to $63.90 \mathrm{mg} \mathrm{kg}^{-1}$ with an average $18.92,20.23$ and $17.14 \mathrm{mg} \mathrm{kg}^{-1}$, respectively. Lower concentration of this form might be attributed to leaching loss of sulphate from soil. These results are in accordance with those of Saradeep kour and Jalali (2008).The non-sulphate sulphur in Vertisols, Inceptisols and Entisols varied from 35.03-3554.27, 206.68-4222.28 and 9.58-1572.00 mg kg-1 with an average 1631.32, 1113.03 and $469.79 \mathrm{mg} \mathrm{kg}^{-1}$, respectively. It was the dominant form among all the other forms. Higher per cent contribution of non-sulphate $\mathrm{S}$ to total $\mathrm{S}$ in these soils may be because of the slightly alkaline nature of these soils and low organic matter together might have resulted in the accumulation of salts in these soils (Bapat et al., 1997).

\section{Correlationcoefficient}

The data on correlation coefficient between physico-chemical properties and forms of sulphur in Vertisol are presented in Table (2).From these results, it was indicated that total sulphur was significantly affected by $\mathrm{pH}$, organic carbon and calcium carbonate content in soil.It could not established any relationship with $\mathrm{EC}, \mathrm{pH}$ and $\mathrm{CaCO}_{3}$ showed negative relationship with total sulphur content which is evident by ' $\mathrm{r}$ ' values of $-0.294^{*}$ and $-0.305^{*}$, respectively.Total S content was positively and significantly related with organic carbon $\left(\mathrm{r}=0.299^{*}\right)$.The various forms of sulphur also found to be influenced by physico-chemical properties of soil.The $\mathrm{pH}$ and $\mathrm{CaCO}_{3}$ content were found to bear negative relationship with available $\mathrm{S}$, organic $\mathrm{S}$, water soluble sulphate $\mathrm{S}$ and non-sulphate $\mathrm{S}$. Negative ' $\mathrm{r}$ 'values of $\left(\mathrm{r}=-0.384^{* *}, \mathrm{r}=-0.288^{*}, \mathrm{r}=-0.308^{*}, \mathrm{r}=-0.312^{*}\right.$ and $\left.\mathrm{r}=-0.292^{*}, \mathrm{r}=-0.310^{*}, \mathrm{r}=-0.336^{*}, \mathrm{r}=-0.307^{*}\right)$ were noticed in between $\mathrm{pH}$ and available $\mathrm{S}$, organic $\mathrm{S}$, water soluble sulphate $\mathrm{S}$ and non-sulphate $\mathrm{S}$ and in between $\mathrm{CaCO}_{3}$ and available $\mathrm{S}$,organic $\mathrm{S}$, water soluble sulphate $S$, respectively.Significant positive relationship with organic carbon was evident from higher ' $r$ ' values for available $\mathrm{S}\left(\mathrm{r}=0.359^{* *}\right)$, organic $\mathrm{S}\left(\mathrm{r}=0.292^{*}\right)$, water soluble sulphate $\mathrm{S}\left(\mathrm{r}=0.344^{*}\right)$ and non-sulphate $\mathrm{S}(\mathrm{r}$ $=0.322 *$ ).Electrical conductivity showed no significant relation with all other forms of sulphur.The results of simple correlation coefficients between physico-chemical properties and forms of total sulphur contentin Inceptisol was negatively and significantly related with $\mathrm{pH}\left(\mathrm{r}=-0.309^{*}\right)$ and $\mathrm{CaCO} 3\left(\mathrm{r}=-0.317^{*}\right)$ but positively with organic carbon $(r=0.312 *)$. Electrical conductivity could not establish any relationship with total sulphur (Table 3).Negative and significant correlation between $\mathrm{pH}$ and available $\mathrm{S}(\mathrm{r}=-0.312 *)$, organic $\mathrm{S}(\mathrm{r}=-$ $\left.0.354^{*}\right)$,water soluble sulphate $\mathrm{S}\left(\mathrm{r}=-0.348^{*}\right)$ and non-sulphate $\mathrm{S}\left(\mathrm{r}=-0.299^{*}\right)$ and in between $\mathrm{CaCO}_{3}$ and available $\mathrm{S}\left(\mathrm{r}=-0.356^{*}\right)$, organic $\mathrm{S}\left(\mathrm{r}=-0.342^{*}\right)$, water soluble sulphate $\mathrm{S}\left(\mathrm{r}=-0.298^{*}\right)$ and non-sulphate $\mathrm{S}(\mathrm{r}=$ $0.322 *)$ were noticed.However,organic carbon showed positive and significant correlation with available $\mathrm{S}(\mathrm{r}$ $\left.=0.299^{*}\right)$,organic $\mathrm{S}\left(\mathrm{r}=0.296^{*}\right)$, water soluble sulphate $\mathrm{S}\left(\mathrm{r}=0.338^{*}\right)$ and non-sulphate $\mathrm{S}\left(\mathrm{r}=0.314^{*}\right)$.Electrical conductivity of soil did not reach to the level of significance. Comparable data on Entisols(Table 4), total S exhibited a negative and significant correlation with $\mathrm{pH}\left(\mathrm{r}=-0.352^{*}\right)$ and $\mathrm{CaCO}_{3}$ content of soil $(\mathrm{r}=-$ $0.442 *)$.Total S were positively and significantly correlated with organic carbon $\left(\mathrm{r}=0.416^{*}\right)$.Correlation studies between different forms of sulphur and physico-chemical properties indicate the negative and significant correlation of $\mathrm{pH}$ and available $\mathrm{S}\left(\mathrm{r}=-0.350^{*}\right)$, organic $\mathrm{S}\left(\mathrm{r}=-0.384^{*}\right)$, water soluble sulphate $\mathrm{S}\left(\mathrm{r}=-0.367^{*}\right)$ and non-sulphate $\mathrm{S}\left(\mathrm{r}=-0.373^{*}\right)$ and $\mathrm{CaCO} 3$ and available $\mathrm{S}\left(\mathrm{r}=-0.419^{*}\right)$, organic $\mathrm{S}\left(\mathrm{r}=-0.392^{*}\right)$, water soluble sulphate $\mathrm{S}\left(\mathrm{r}=-0.430^{*}\right)$ and non-sulphate $\mathrm{S}(\mathrm{r}=-0.393 *)$. Positive and significant correlation of organic carbon with available $\mathrm{S}\left(\mathrm{r}=0.392^{*}\right)$, organic $\mathrm{S}\left(\mathrm{r}=0.439^{*}\right)$, water soluble sulphate $\mathrm{S}\left(\mathrm{r}=0.386^{*}\right)$ and non-sulphate $\mathrm{S}(\mathrm{r}$ $\left.=0.373^{*}\right)$ was also observed.EC of soil could not established any relation with all the forms of sulphur. The negative relationships of almost all the forms of sulphur and $\mathrm{pH}$ and $\mathrm{CaCO}_{3}$ content revealed that the presence of $\mathrm{H}^{+}$and $\mathrm{OH}^{-}$ions on soil complex, where $\mathrm{SO}_{4}{ }^{2-}$ ions are attracted to $\mathrm{H}^{+}$ions and formation of insoluble compounds of $\mathrm{S}$ with $\mathrm{Fe}$ and $\mathrm{Al}$ oxides(Borkotoki and Das, 2008).The positive relationships of almost all forms of sulphur with organic carbon were observed.The observed significant positive correlation with all forms of sulphur with organic carbon suggests that the sulphur supplying power of these soils having largely dependent upon these parameter(Basumatari et al., 2010).

\section{Conclusion}

Soils are classified into Vertisols, Inceptisols and Entisols. Almost soil samples, $\mathrm{pH}$ of soil was alkaline in nature, whereas EC of the soil was in safe limit for the crop growth. The organic carbon status was low to high andcalcareous in nature. Low in available nitrogen,phosphorus and high potassium were observed in 
oilseed growing soils of study area. However, the exchangeable $\mathrm{Ca}$ was in sufficient quantity, while exchangeable Mg varied from low to high. The different forms of sulphur were identified from the investigated soils. The forms of sulphur present in these soils are in the order of total sulphur, non-sulphate sulphur, organic sulphur, water soluble sulphur and available sulphur. The deficiency of sulphur is $22.91,33.33$ and 18.75 per cent in Vertisols, Inceptisols and Entisols, respectively. Simple correlation analysis depicted the fact that $\mathrm{pH}$ and $\mathrm{CaCO}_{3}$ were correlated significantly and negatively with different forms of sulphur. However, organic carbon was positively and significantly related with all the forms of sulphur.

\section{References}

[1]. Aulakh, M. S. and Dev, G. (1976) Profile distribution of sulphur in some soil series of Sangrur district Punjab. Journal of the Indian Society of Soil Science, 24:308-313.

[2]. Bapat, P.N., Sharma, B.L., Rathod, G.S. and Khamparia, R.S. (1997) Forms of sulphur and suitability of sulphur extractions for linseed crop growth grown on Vertisols of MP.Journal of the Indian Society of Soil Science, 45: 523-525.

[3]. Basumatari Anjali,Das,K.N.and Borkotoki Bikram (2010) Interrelationships of sulphur with soil properties and its availability index in some rapeseed growing Inceptisols of Assam. Journal of the Indian Society of Soil Science, 58 : 394-402.

[4]. Bhattacharyya, T., Pal, D.K. and Deshpande, S.B. (1993) Genesis and transformation of minerals in the formation of red (Alfisols) and black (Inceptisols and Vertisols) soils in Deccan basalt in the Western Ghats, India. Journal of the Indian Society of Soil Science, $\mathbf{4 4}:$ 159-171.

[5]. Borkotoki, B. and Das, K.N.(2008) Forms of sulphur and their relationships with soil properties in Entisols, Inceptisols and Alfisols of Assam.Journal of the Indian Society of Soil Science, 56:186-191.

[6]. Chesnin, L. and Yein, C.H. (1951) Turbidimetric determination of available sulphur. Soil Science Society of America, 15:149-151.

[7]. Dharakanath, K.,Mohite, A.V. and Patil, M.D.(1995) Sulphur status of some important soil series of vertisols of Maharashtra state.Journal of Indian Society of Soil Science, 43: 364-367.

[8]. Evans, C.A. and Rost, C.O. (1945) Total organic sulphur of Minnessotto soils. Australian Journal of Agriculture Research, 10:340352 .

[9]. Jackson, M.L. (1973) Soil Chemical analysis, Prentice Hall of India Private Ltd. New Delhi.

[10]. Jagtap, V.R. (2007) Physico-chemical characteristics and status of NPK and some micronutrients in soils from Chakur and Shiruranantpal tahsils of Latur district. M.Sc. (Agri) thesis submitted to M.A.U. Parbhani.

[11]. Jibhakate, S.B., Bhende, S.N., Kharche, V.K. and Sevalakshmi,V. (2009) Physico-chemical status of soils of Katol tahasil in Nagpur district. Journal of Soils and Crops, 19:122-128.

[12]. Mahesh kumar, Singh, S.K., Raina, P. and Sharma, B.K. (2011) Status of available major and micronutrients in arid soils of Churu district of Western Rajasthan. Journal of the Indian Society of Soil Science, 59:188-192.

[13]. Malewar, G.U. (1995) Micronutrient availability as influenced by cropping pattern in Marathwada region of Maharashtra. Journal of Maharashtra Agricultural University, 20: 330-333.

[14]. Malewar, G.U. and Syed Ismail (1997) Sulphur in Balanced fertilization in Western India. Proc.TSI/FAI/IFA symposium held at New Delhi.Feb.13-14,pp SI-4/1-20.

[15]. Mali, C.V. and Syed Ismail (2002) Characterization and fertility status of Marathwada soils, sulphur and micronutrients in soil resource inventory of Marathwada,Department of Agricultural Chemistry and Soil Science,MAU,Parbhani. pp:72-87.

[16]. Pal, D.K., Bhattacharyya, T., Ray, S.K., Chandran, P., Srivastava, P., Durge, S.L. and Bhuse, S.R. (2006) Significance of soils modifiers (Ca Zeolites and gypsum) in naturally degraded Vertisols of peninsular India in redefining the sodic soils. Geoderma, 136 : 210-229.

[17]. Panse, V. G. and Sukhatme, P. V. (1985) Statistical Methods for Agricultural Workers, ICAR, New Delhi

[18]. Patil, Y.M. and Sonar, K.R. (1994) Status of major and micronutrients of swell-shrink soils of Maharashtra. Journal Maharashtra Agricultural University, 19: 169-172.

[19]. Sarabdeep Kour and Jalali (2008) Forms of sulphur and their relationship in soils of different agroclimatic zones of Jammu Region. Journal of the Indian Society of Soil Science 56 : 309-312.

[20]. Subbiah, B.V. and Asija, G.L. (1956) Rapid procedure for the estimation of available nitrogen in soil. Currunt Science, 25 : 259260 .

[21]. Vineetha, V. and Malewar, G.U. (2009) Physico-chemical properties and fertility status of sweet orange orchards in Marathwada region. Indian Journal of Agricultural Chemistry, 42: 71-78.

[22]. Williams, C.H. and Steinbergs, A. (1959) Soil sulphur fraction as chemical indices of available sulphur in some Australian soils. Australian Journal of Agricultural Research,10 : 340-350.

[23]. Yadav, R.L. and Meena, M.C. (2009) Available micronutrient status and their relationship with soil properties of Degana soil series of Rajsthan. Journal of the Indian Society of Soil Science,57: 90-92.

Table 1. Range and average value of soil site characteristics and forms of sulphur in soils

\begin{tabular}{|c|c|c|c|c|c|c|c|c|c|c|c|c|c|c|}
\hline Soil order & $\mathrm{pH}$ & $\begin{array}{c}\mathrm{EC} \\
\left(\mathrm{dSm}^{-1}\right)\end{array}$ & $\begin{array}{l}\text { O.C. } \\
(\%)\end{array}$ & $\begin{array}{c}\mathrm{CaCO}_{3} \\
(\%)\end{array}$ & $\underset{\left(\mathrm{kg} \mathrm{ha}{ }^{-1}\right)}{\mathrm{N}}$ & $\begin{array}{c}\mathrm{P}_{2} \mathrm{O}_{5} \\
\left(\mathrm{~kg} \mathrm{ha}^{-1}\right)\end{array}$ & $\begin{array}{c}\mathrm{K}_{2} \mathrm{O} \\
\left(\mathrm{kgha}^{-1}\right)\end{array}$ & $\begin{array}{c}\mathrm{Ca} \\
\left(\mathrm{cmol}^{-1}\right. \\
\left.\left(\mathrm{p}^{+}\right) \mathrm{kg}^{-1}\right)\end{array}$ & $\begin{array}{c}\mathrm{Mg} \\
\left(\mathrm{cmol}^{+}\right. \\
\left.\left(\mathrm{p}^{+}\right) \mathrm{kg}^{-1}\right)\end{array}$ & $\begin{array}{c}\text { Total S } \\
\left(\mathrm{mgkg}^{-1}\right)\end{array}$ & $\begin{array}{c}\text { Avai. } \\
\text { sulphur } \\
\left(\mathrm{mgkg}^{-1}\right)\end{array}$ & $\begin{array}{l}\text { Organic } \\
\text { sulphur } \\
\left(\mathrm{mgkg}^{-1}\right)\end{array}$ & $\begin{array}{c}\text { Water } \\
\text { soluble } \\
\text { sulphur } \\
\left(\mathrm{mgkg}^{-1}\right)\end{array}$ & $\begin{array}{c}\text { Non- } \\
\text { sulphate } \\
\text { sulphur } \\
\left(\mathrm{mgkg}^{-1}\right)\end{array}$ \\
\hline Vertisol & $\begin{array}{c}6.02- \\
8.89 \\
(7.71)\end{array}$ & \begin{tabular}{c|}
$0.10-$ \\
0.65 \\
$(0.35)$
\end{tabular} & $\begin{array}{l}1.30- \\
18.90 \\
(5.02)\end{array}$ & $\begin{array}{l}35.0-15 \\
(94.79)\end{array}$ & $\begin{array}{c}99.91- \\
487.16 \\
(178.97)\end{array}$ & $\begin{array}{l}1.14- \\
20.62 \\
(6.77)\end{array}$ & $\begin{array}{c}118.7- \\
844.60 \\
(432.37)\end{array}$ & $\begin{array}{l}11.50- \\
50.50 \\
32.74)\end{array}$ & $\begin{array}{l}7.90- \\
28.60 \\
(17.64)\end{array}$ & $\begin{array}{c}19.50- \\
3652.00 \\
(1678.16)\end{array}$ & $\begin{array}{c}3.30- \\
30.33 \\
(15.05)\end{array}$ & $\begin{array}{c}3.00- \\
84.30 \\
(31.78)\end{array}$ & $\begin{array}{c}4.80- \\
58.26 \\
(18.92)\end{array}$ & $\begin{array}{c}35.03- \\
3554.27 \\
(1631.32)\end{array}$ \\
\hline Inceptisol & $\begin{array}{c}6.43- \\
8.92 \\
(7.60)\end{array}$ & $\begin{array}{c}0.12- \\
0.49 \\
(0.22)\end{array}$ & $\begin{array}{l}1.40- \\
15.0 \\
(4.41)\end{array}$ & $\begin{array}{l}35.0-14 \\
(93.62)\end{array}$ & $\begin{array}{c}111.08- \\
559.08 \\
(175.31)\end{array}$ & $\begin{array}{l}1.03- \\
20.47 \\
(6.74)\end{array}$ & $\begin{array}{c}120.8- \\
716.30 \\
(427.26)\end{array}$ & $\begin{array}{c}13.00- \\
48.90 \\
(30.54)\end{array}$ & $\begin{array}{c}7.50-28.3 \\
(14.22)\end{array}$ & $\begin{array}{c}347.50- \\
4300.00 \\
(1172.78)\end{array}$ & $\begin{array}{c}3.32- \\
28.92 \\
(15.69)\end{array}$ & $\begin{array}{l}11.36- \\
176.00 \\
(44.05)\end{array}$ & $\begin{array}{c}6.30- \\
68.30 \\
(20.23)\end{array}$ & $\begin{array}{l}206.68 \\
4222.28 \\
(1113.03)\end{array}$ \\
\hline Entisol & $\begin{array}{c}7.09- \\
8.43 \\
(7.80)\end{array}$ & $\begin{array}{c}0.08- \\
0.37 \\
(0.19)\end{array}$ & $\begin{array}{c}1.40- \\
11.4 \\
(3.94) \\
\end{array}$ & $\begin{array}{c}37.00- \\
114 \\
(81.00)\end{array}$ & $\begin{array}{c}101.64- \\
606.19 \\
(189.12)\end{array}$ & $\begin{array}{l}1.65 \\
10.57 \\
(5.82)\end{array}$ & $\begin{array}{c}130.9- \\
835.60 \\
(414.29)\end{array}$ & $\begin{array}{c}15.20- \\
49.0 \\
(34.44)\end{array}$ & $\begin{array}{c}7.50-27.8 \\
(17.49)\end{array}$ & $\begin{array}{l}192.50- \\
1625.00 \\
(543.60)\end{array}$ & $\begin{array}{c}2.42- \\
28.85 \\
(15.95)\end{array}$ & $\begin{array}{l}10.96- \\
120.30 \\
(57.85)\end{array}$ & $\begin{array}{c}5.20 \\
63.90 \\
(17.14)\end{array}$ & $\begin{array}{c}9.58- \\
1572.00 \\
(469.79)\end{array}$ \\
\hline
\end{tabular}

Parenthesis "()"indicates average mean value 
Comparative Studies on Dynamics Soil Properties and Forms of Sulphur in Oilseed Growing .....

Table 2. Correlation between physico-chemical properties and forms of sulphur in Vertisols

\begin{tabular}{cccccc}
\hline $\begin{array}{c}\text { Physico-chemical } \\
\text { properties }\end{array}$ & Total Sulphur & Available Sulphur & $\begin{array}{c}\text { Organic } \\
\text { Sulphur }\end{array}$ & $\begin{array}{c}\text { Water soluble } \\
\text { sulphate Sulphur }\end{array}$ & Non-sulphate Sulphur \\
\hline pH & $-0.294^{*}$ & $-0.384^{* *}$ & $-0.288^{*}$ & $-0.308^{*}$ & $-0.312^{*}$ \\
EC & -0.169 & -0.184 & -0.204 & -0.055 & -0.178 \\
O.C & $0.299^{*}$ & $0.359 * *$ & $0.292^{*}$ & $0.344^{*}$ & $0.322^{*}$ \\
$\mathbf{C a C O}_{3}$ & $-0.305^{*}$ & $-0.292^{*}$ & $-0.310^{*}$ & $-0.336^{*}$ & $-0.307 *$ \\
\hline
\end{tabular}

* Significant at $\mathrm{p}=0.05$ level: -0.273

** Significant at $\mathrm{p}=0.01$ level: -0.354

Table 3. Correlation between physico-chemical properties and forms of sulphur in Inceptisols

\begin{tabular}{cccccc}
\hline $\begin{array}{c}\text { Physico- } \\
\text { chemical } \\
\text { properties }\end{array}$ & Total Sulphur & Available Sulphur & $\begin{array}{c}\text { Organic } \\
\text { Sulphur }\end{array}$ & $\begin{array}{c}\text { Water soluble } \\
\text { sulphate Sulphur }\end{array}$ & Non-sulphate Sulphur \\
\hline pH & $-0.309^{*}$ & $-0.312^{*}$ & $-0.354^{*}$ & $-0.348^{*}$ & $-0.299^{*}$ \\
EC & -0.027 & 0.146 & 0.272 & -0.223 & -0.045 \\
O.C & $0.312^{*}$ & $0.299^{*}$ & $0.296^{*}$ & $0.338^{*}$ & $0.314^{*}$ \\
$\mathbf{C a C O}_{3}$ & $-0.317^{*}$ & $-0.356^{*}$ & $-0.342^{*}$ & $-0.298^{*}$ & $-0.322^{*}$ \\
\hline
\end{tabular}

* Significant at $\mathrm{p}=0.05$ level: -0.288

** Significant at $\mathrm{p}=0.01$ level: -0.372

Table4. Correlation between physico-chemical properties and forms of sulphur in Entisols

\begin{tabular}{cccccc}
\hline $\begin{array}{c}\text { Physico- } \\
\text { chemical } \\
\text { properties }\end{array}$ & Total Sulphur & Available Sulphur & Organic Sulphur & $\begin{array}{c}\text { Water soluble } \\
\text { sulphate Sulphur }\end{array}$ & Non-sulphate Sulphur \\
\hline pH & $-0.352^{*}$ & $-0.350^{*}$ & $-0.384^{*}$ & $-0.367^{*}$ & $-0.373^{*}$ \\
EC & -0.021 & -0.201 & -0.026 & 0.003 & -0.012 \\
O.C & $0.416^{*}$ & $0.392^{*}$ & $0.439^{*}$ & $0.386^{*}$ & $0.373^{*}$ \\
$\mathbf{C a C O}_{3}$ & $-0.442^{*}$ & $-0.419 *$ & $-0.392^{*}$ & $-0.430^{*}$ & $-0.393^{*}$ \\
\hline
\end{tabular}

* Significant at $\mathrm{p}=0.05$ level: -0.348

** Significant at $\mathrm{p}=0.01$ level: -0.444 